\title{
Auditory complaints and audiologic assessment in children with surgically repaired cleft lip and palate
}

\author{
Jaqueline Lourenço Cerom 1 , Maria Renata José1, Fabiana de Souza Pinto Azenha², Camila de Cássia Macedo³, Kátia de Freitas \\ Alvarenga ${ }^{4}$, Andréa Cintra Lopes ${ }^{5}$, Mariza Ribeiro Feniman'.
}

1) Speech Therapist. Speech-Language Pathology and Audiology Graduate Program (Master's Degree) in the field of Communication Disorders, Bauru School of Dentistry, University of São Paulo-USP, Bauru (SP), Brazil

2) Master of Science. Master's Degree in Science in the field of Communication Disorders, Audiologist at the Speech-Language Pathology and Audiology Clinic of the Bauru School of Dentistry, University of São Paulo-USP

3) Master of Rehabilitation Sciences. Master's Degree in Rehabilitation Sciences in the field of Orofacial Clefts and Related Anomalies, Graduate Program (Doctorate) in Rehabilitation Sciences, Hospital for Rehabilitation of Craniofacial Anomalies.

4) Associate Professor. Associate Professor of the Speech-Language Pathology and Audiology Department, Bauru School of Dentistry, University of São Paulo-USP, Bauru (SP), Brazil.

5) PhD. Associate Professor of the Speech-Language Pathology and Audiology Department, Bauru School of Dentistry, University of São Paulo-USP, Bauru (SP), Brazil.

6) Professor. Full Professor of the Speech-Language Pathology and Audiology Department, Bauru School of Dentistry, University of São Paulo-USP, Bauru (SP), Brazil.

Institution: Faculdade de Odontologia de Bauru - USP.

Bauru/SP - Brazil

Mailing address: Mariza Ribeiro Feniman - Departamento de Fonoaudiologia - Universidade de São Paulo - Campus USP Bauru - Alameda Dr. Octávio Pinheiro Brisolla, 9-75 - Bauru / SP - Brazil - Zip code: 17012-901 - E-mail: keline_jlc@hotmail.com

Article received on October 24th, 2012. Article accepted on February 26th, 2013

\section{SUMMARY}

Introduction: At the initial consultation, the speech-language pathologist and audiologist may consider possible diagnostic hypotheses based on the child's history and the parents' complaint.

Aim: To investigate the association of hearing complaints with the findings obtained in the conventional audiologic assessment in children with cleft lip and palate. Retrospective study.

Methods: We analyzed medical charts of 1000 patients with cleft lip and palate who underwent surgical repair between 1988 and 1995 at a mean age of 6 years 8 months. We excluded charts with records of inconsistent audiological responses and charts with missing data for any of the audiologic evaluations considered. Thus, the sample consisted of 393 records.

Results: Two hundred thirty-nine patients presented hearing loss in one or both ears, but only $3.8 \%$ reported hearing complaints. The most frequent were otorrhea followed by otalgia. There was no statistical significance between the complaint and gender $(\mathrm{p}=0.26)$ nor between the complaint and hearing loss $(\mathrm{p}=0.83)$.

Conclusion: This study showed no association between the hearing complaint and the conventional audiologic assessment. Keywords: Hearing Loss; Cleft Palate; Child; Audiometry; Hearing.

\section{INTRODUCTION}

Cleft lip and palate is a craniofacial anomaly caused by failure in the fusion of embryonic facial processes (1). It is the most common malformation, occurring in approximately 1 per 500-700 births and, this ratio vary considerably across ethnic grouping. This congenital deformity results in esthetic and functional alterations, depending on the affected structures.

Otological and hearing problems have a high prevalence in the population with cleft lip and palate compared with the unaffected population, because this malformation affects important structures in the tympanic ossicular chain, thereby predisposing to otitis media with consequent hearing loss. Therefore, special attention should be given to this aspect (2-4).
During the initial consultation, the speech-language pathologist and audiologist may consider possible diagnostic hypotheses on the basis of the child's history and the parents' complaint (5).

Earlier diagnosis of auditory difficulties in children results in better intervention and support in cognitive and social development. Considering the importance of early diagnosis of hearing impairment and the knowledge of language development, the situation with regards to identification and early diagnosis requires clarification. This may facilitate introduction and performance of actions that prevent delayed language development in children with hearing difficulties (6).

Therefore, the purpose of this study was to verify the association of auditory complaints with the findings of the conventional audiologic assessment in children with 
cleft lip and palate who were treated at a specialized hospital in a city located in the state of São Paulo.

\section{METHOD}

The present study was approved by the Ethics Committee of Bauru School of Dentistry (FOB/USP), process number 049/2008. This retrospective study utilized 1000 randomly selected charts of patients with cleft lip and palate who underwent surgical repair between 1988 and 1995. The survey was conducted in 2009 in a hospital of interdisciplinary treatment.

We verified data regarding gender, age, speech, language, and audiologic history, in addition to data concerning conventional audiologic assessment (puretone audiometry).

The patient's audiologic history was verified in the interview, with an emphasis on hearing complaints. In the audiologic assessments we verified the presence or absence and the type of hearing loss. The audiologic assessments were performed with a Midimate 622 audiometer.

We excluded medical charts with records of inconsistent audiologic responses and charts with missing data for any of the audiologic evaluations considered. Therefore, we included the records of 393 patients in the statistical analysis.

Of the 393 charts studied, 262 (66.6\%) belonged to boys and 131 (33.3\%) belonged to girls aged between 4 years and 10 years 11 months.

The Qui-square test was used for the statistical analysis. The minimum level of significance was set at
$5 \%(\mathrm{p}<0.05)$. Categorical variables were arranged in tables.

\section{RESULTS}

Of the 393 patients, 239 presented hearing loss in one or both ears, which was conductive, mixed, or sensorineural. The conductive hearing loss was predominant (Table 1).

Only 15 patients reported auditory complaints in the speech, language, and audiologic history (3.8\%); otorrhea $(\mathrm{n}=10)$ was the most frequent finding in these patients followed by otalgia ( $n=9)$. In contrast, $378(96.18 \%)$ did not report complaints regarding hearing (Table 2).

Among the 15 individuals who reported auditory complaints, there were 8 boys and 7 girls, and there was no correlation between the complaint and the gender ( $p=$ 0.26). Most patients with auditory complaints in the interview presented with hearing loss in at least one ear $(p \leq 0.001)$. The results of the audiologic assessment of these patients are reported in Table 3.

Not all patients with hearing loss had complaints related to hearing. We analyzed the 378 (96.18\%) charts of children with no complaints about hearing and considered the presence or absence and the type of hearing loss in the audiologic assessment (Table 4).

We did not find a significant association $(\mathrm{p}=0.83)$ between the presence of hearing complaints and hearing loss in all the patients $(n=393)$. Considering each ear (right and left) of all the 393 patients $(n=786)$, the otoscopy findings were normal in 755 ears (96.06\%) and abnormal in only $31(3.94 \%)$.

Table I . Distribution (\%) of the audiologic assessment in each ear of all patients.

\begin{tabular}{lccccc}
\hline & Normal N(\%) & Conductive $N(\%)$ & Mixed N(\%) & SensorineuralN(\%) & Total $(\%)$ \\
Hearing loss(RE) & $275(69.97)$ & $1 \mid 2(28.50)$ & $4(1.02)$ & $2(0.51)$ & $393(100)$ \\
Hearingloss(LE) & $272(69.21)$ & $1 \mid 4(29.01)$ & $5(1.27)$ & $2(0.51)$ & $393(100)$ \\
\hline
\end{tabular}

$\mathrm{N}$, number of patients

$\%$, percentage of patients

Table 2. Distribution (\%) of the auditory complaints of all patients.

\begin{tabular}{lccccc}
\hline Complaint & Hearingloss N(\%) & OtalgiaN(\%) & OtorrheaN(\%) & TinnitusN(\%) & ItchinessN(\%) \\
\hline Bilateral & $3(0.76)$ & $7(1.78)$ & $7(1.78)$ & $5(1.27)$ & $2(0.50)$ \\
Leftear & - & $2(0.50)$ & $2(0.50)$ & - & - \\
Rightear & - & - & $1(0.25)$ & - & - \\
\hline
\end{tabular}

$\mathrm{N}$, number of patients

$\%$, percentage of patients 
Table 3. Results of the audiologic assessment of children with auditory complaints

\begin{tabular}{lccc}
\hline & Conductive loss N(\%) & Mixed loss N(\%) & Normal hearing N(\%) \\
\hline Rightear & $13(86.66)$ & - & $2(13.33)$ \\
Leftear & $12(80)$ & $1(6.66)$ & $2(13.33)$ \\
\hline
\end{tabular}

$\mathrm{N}$, number of patients

$\%$, percentage of patients

Table 4. Type of hearing loss diagnosed and presence of normal hearing in children with no hearing complaints.

\begin{tabular}{lcccc}
\hline & $\begin{array}{c}\text { Conductive loss } \\
\mathrm{N}(\%)\end{array}$ & $\begin{array}{c}\text { Mixed loss } \\
\mathrm{N}(\%)\end{array}$ & Sensorioneural loss & $\begin{array}{c}\text { Normal hearing } \\
\mathrm{N}(\%)\end{array}$ \\
\hline Rightear & $99(26,19)$ & $4(1,05)$ & $2(0,52)$ & $273(72,22)$ \\
Leftear & $102(26,98)$ & $4(1,05)$ & $2(0,52)$ & $270(71,42)$ \\
\hline
\end{tabular}

\section{DISCUSSION}

Hearing disorders in children should be identified and treated early, because even mild hearing loss can influence the way sounds are processed and affect language development; consequences include speech production with phonetic errors, learning difficulties, poor reading comprehension, and unsatisfactory academic performance, as well as inadequate social skills $(7,8)$.

It is noteworthy that hearing impairment in children with cleft lip and palate is a secondary feature, and for this reason, hearing complaints are often not reported by parents.

However, in cases of mild hearing loss, symptoms may go unnoticed by the individual and/or family (9), or the individual may present asymptomatic auditory alterations, which highlights the importance of early audiologic diagnosis to enable appropriate treatment.

In a study conducted at the Speech-Language Pathology and Audiology Department of the Baleia Hospital in Belo Horizonte, $85 \%$ of the children aged between 3 and 12 years with surgically repaired cleft palate did not present auditory complaints (10). This is corroborated by the data obtained in this study, in which $96 \%$ had no auditory complaints.

Regarding the types of auditory complaint, a study (11) conducted with 150 medical records showed that 83\% of the sample had some type of hearing complaint, the most frequent being unilateral or bilateral hearing loss (64\%). Otitis and otorrhea (current or previous) were more prevalent in the presurgical groups undergoing tympanoplasty and tympanomastoidectomy. The least reported complaint was otalgia, which was present in only
Table 5. Results of conventional otoscopy in all patients.

\begin{tabular}{lccc}
\hline & Normal(\%) & Altered(\%) & TOTAL(\%) \\
\hline OtoscopyRE & $378(96.2)$ & $15(3.8)$ & $393(100)$ \\
OtoscopyLE & $377(96.0)$ & $16(4.0)$ & $393(100)$ \\
\hline
\end{tabular}

$37 \%$ of the sample. Because serous otitis media does not cause pain, it is a "silent" pathology, going unnoticed by the individual or family (12).

However, the literature is generally limited to the presence or absence of hearing complaints and does not note the type of complaint most commonly found in individuals with cleft lip and palate (9).

In this study, the main complaints reported by parents of children with hearing complaints were related to the conductive system, because the most frequent complaints reported in the audiologic interview were otitis and otorrhea.

We observed that even in cases where there was no complaint of hearing loss or hearing difficulties, hearing loss was detected. From the analysis of the 378 records of children with no history of auditory complaints, 108(28.57\%) had some type of hearing loss in the audiologic assessment, the majority (94\%) being conductive hearing loss in at least one ear. Hearing loss is unnoticeable until its effects translate into oral language impairment, and rehabilitation at this stage may be less effective. Thus, early detection of this disorder is critical (13).

Parents may fail to identify hearing loss because the presence of otitis media with effusion (OME) in children is 
usually inconspicuous and does not cause pain (14). Depending on age, complaints may not be specific and include fever, irritability, moderate or intense crying, anorexia, diarrhea, and vomiting (15).

Considering that our study sample represents schoolaged children, recognition of hearing difficulties and early diagnosis of the severity of the hearing loss, together with preventative actions for consequences related to auditory and communication skills, are important factors in the academic development of a student with hearing loss (16).

Another study that sought to determine the frequency of hearing complaints in children with learning difficulties pointed out that complaints of tinnitus and discomfort to sounds were the most frequent in this group (17). Our study found complaints of tinnitus in $33.33 \%$ of the children with hearing complaints, which might suggest, in addition to possible hearing alterations, other impairments of metabolic or circulatory origin.

We consider the low presence of alterations on otoscopy (3.94\%) due to use of conventional otoscopy. Studies $(18,19)$ support the use of pneumatic otoscopy as a diagnostic tool, which is suitable, inexpensive, and can predict the presence of fluid (effusion) in the middle ear. The position and mobility of the eardrum are considered the most important diagnostic indicators.

The results of this study suggest the use of questionnaires and checklists, with greater specificity and sensitivity for otologic and auditory problems, in the population with cleft lip and palate.

Parents require fundamental guidelines so they can recognize even mild hearing difficulties in their children and, therefore, minimize the disorders that may arise as a result of sensory deprivation.

\section{CONCLUSION}

The present study showed no association between the auditory complaints and the conventional audiologic assessment.

\section{REFERENCES}

1. Murray JC. Gene/environment causes of cleft lip and/or palate. Clinical Genetics. 2002;61(4):248-56.

2. Pegoraro-Krook MI, Souza JCRD, Teles-Magalhães LC, Feniman MR. Intervenção fonoaudiológica na fissura palatina. In: Ferreira LP, Befi-Lopes DM, Limongi SCO, editors.
Tratado de Fonoaudiologia. São Paulo: Roca; 2004. p. 339455 .

3. Arnold WH, Nohadani N, Koch KH. Morphology of the auditory tube and palatal muscles in a case of bilateral cleft palate. Cleft Palate Craniofac J. 2005;42(2):197-201.

4. Chu KM, McPherson B. Audiological status of Chinese patients with cleft lip/palate. Cleft Palate Craniofac J. 2005;42(3):280-5.

5. NorthernJL, Downs MP. Audição em crianças. 3rd ed. São Paulo: Manole; 1989.

6. Sígolo C, Lacerda CBF de. Da suspeita à intervenção em surdez: caracterização deste processo na região de Campinas/SP. J. Soc. Bras. Fonoaudiol. 2011;23(1):32-7.

7. Balbani, APS, Montovani JC. Impacto das otites médias na aquisição da linguagem em crianças. J. Pediatr. (Rio J.). 2003;79(5):391-6.

8. Amaral MIR do, Martins JE, Santos MFC dos. Estudo da audição em crianças com fissura labiopalatina não sindrômica. Braz.J. Otorhinolaryngol. 2010;76(2):164-71.

9. Piazentin-Penna SHA. Identificação auditiva em crianças de 3 a 12 meses de idade com fissura labiopalatina [dissertation]. [Bauru]: Hospital de Reabilitação de Anomalias Craniofaciais; 2002. 157 p.

10. Souza D, Di Ninno CQ, Borges GP, Silva TM, Miranda ES. Perfil audiológico de indivíduos operados de fissura de palato no Hospital da Baleia de Belo Horizonte. ACTA ORL. 2006;24(3):170-3.

11. Santos FR dos, Piazentin-Penna SHA, Brandão GR, Avaliação audiológica pré-cirurgia otológica de indivíduos com fissura labiopalatina operada. Rev. CEFAC. 2011;13(2):271-80.

12. Hubig DOC, Costa OA. Otite média: considerações em relação à população de creche. In: Lichitig I, Carvalho RMM, org. Audição: abordagens atuais. São Paulo: Pró-Fono; 1997. p. 91-117.

13. Gatto C, Tochetto TM. Deficiência auditiva infantil implicações e soluções. Rev. CEFAC. 2007;9(1):110-5.

14. Lemos ICC, Feniman MR. Teste de Habilidade de Atenção Auditiva Sustentada (THAAS) em crianças de sete anos com fissura labiopalatina. Braz. J. Otorhinolaryngol. 2010;76(2):199-205.

15. Ferreira S. Otite média em crianças: Incidência e 
consequências [thesis]. [Campo Grande]: Centro de especialização em Fonoaudiologia clínica; 2000. 34 p.

16. Delgado-Pinheiro EMC, Omote S. Conhecimentos de professores sobre perda auditiva e suas atitudes frente à inclusão. Rev. CEFAC. 2010;12(4):633-40.

17. Vitorelli PT, Doná F, Bataglia P, Scharlach RC, Kasse CA, Branco-Barreiro FCA. Ocorrência de queixas auditivas em escolares com e sem dificuldade de aprendizagem. Revista Equilíbrio Corporal e Saúde. 2009;1(1):55-61.
18. de Melker RA. Evaluation of the diagnostic value of pneumatic otoscopy in primary care using the results of tympanometry as a reference standard. Br J Gen Pract. 1993;43(366):22-4.

19. Harris PK, Hutchinson KM, Moravec J. The use of tympanometry and pneumatic otoscopy for predicting middle ear disease. Am J Audiol. 2005;14(1):3-13. 